\title{
Geociências
}

\section{Sedimentological characterization of the quaternary deposits in the region between Marília and Presidente Prudente, São Paulo State, Brazil}

\author{
(Caracterização sedimentológica dos depósitos \\ quaternários da região entre Marília e Presidente Prudente, \\ Estado de São Paulo, Brasil)
}

Alethéa Ernandes Martins Sallun

Doutora, Pesquisadora Científica do Instituto Geológico (IG/SMA-SP)

E-mail: alethea@igeologico.sp.gov.br

Kenitiro Suguio

Prof. Emérito, Instituto de Geociências (IGc-USP), Prof. Titular, Universidade Guarulhos (UnG-CEPPE)

E-mail: kenitirosuguio@hotmail.com

\section{Resumo}

Para caracterização sedimentológica e estudos de proveniência de depósitos coluviais de idade quaternária (9 \pm 1 a $980 \pm 100 \mathrm{kaA} . P$. - datados por luminescência), foram realizadas análises textural e mineralógica. Tais depósitos ocorrem extensivamente entre Marília e Presidente Prudente (SP), superpostos às rochas sedimentares do Grupo Bauru ou rochas basálticas do Grupo Serra Geral (Formação Serra Geral), ambas de idade cretácica. São distribuídos irregularmente na região e foram estudados por métodos sedimentológicos e morfológicos. Os depósitos coluviais são compostos de areias muito finas a grossas e inconsolidadas, em sua maioria formada por grãos monocristalinos de quartzo, de coloração avermelhada por impregnação de óxidos e hidróxidos de ferro. As análises granulométricas mostraram que os depósitos coluviais apresentam contribuição maior de areia argilosa do que as rochas sedimentares sotopostas. $\mathrm{O}$ estudo microscópico de minerais pesados transparentes não-micáceos mostrou que, tanto nas areias finas, quanto nas muito finas, zircão, turmalina, estaurolita e rutilo estão presentes em todas as amostras analisadas. As diferenças granulométricas constatadas entre os depósitos coluviais e as rochas sedimentares do Grupo Bauru são perfeitamente explicáveis por processos pedogenéticos.

Palavras-chave: Quaternário, colúvio, caracterização sedimentológica, minerais pesados, São Paulo.

\begin{abstract}
Sedimentologic characterization and provenance studies of quaternary colluvial deposits $(9 \pm 1$ to $980 \pm 100$ ky B.P. - dated by luminescence) were based on textural and mineralogical analyses. These deposits occur extensively between Marilia and Presidente Prudente (São Paulo State, Brazil), superimposed on the Bauru Group sedimentary rocks or the Serra Geral Formation basaltic rocks, both of Cretaceous age. They are distributed irregularly throughout the study area and are studied by sedimentologic and morphologic methods. These deposits are composed of very fine to coarse-grained unconsolidated sands, mostly constituted by quartzose monocrystalline grains reddened by iron oxide and hydroxide impregnation. Analyses of grain sizes indicated that total granulometric distributions are richer in the clay fraction than in the sedimentary rocks located. Nonmicaceous transparent heavy minerals studied microscopically in fine-grained as well as in very finegrained sands showed that zircon, tourmaline, staurolite and rutile are present in all the samples. Differences in grain sizes among the colluvial deposits and the Bauru Group sedimentary rocks are attributable to pedogenetic processes.
\end{abstract}

Keywords: Quaternary, colluvio-eluvial, sedimentological characterization, heavy minerals, São Paulo. 


\section{Introduction}

Quaternary deposits related to distinct geologic contexts can be found at several locations in the State of São Paulo, Brazil. Due to their lack of structure and similarity with material resulting from the weathering of regional rock, colluvial deposits are sometimes confused with eluvial deposits. In the studied area between Marília and Presidente Prudente (western portion of the State of São Paulo) there are Quaternary deposits superimposed on Cretaceous sandstones of the Marília and Adamantina formations (Bauru Group) and on Cretaceous basalts of the Serra Geral Formation (São Bento Group), both belonging to the Paraná Sedimentary
Basin (Dias Brito et alli, 2001, Renne et alli, 1992, Figure 1).

The Quaternary deposits were subdivided into colluvial and alluvial deposits, according to compositional similarities and provenance interpretations compared to present morphologic features of the study area. Luminescence dating proved the deposits to be from the Pleistocene ages for the colluvial ( $9 \pm 1$ to $980 \pm 100 \mathrm{ka}$ B.P.) and the alluvial ( $14 \pm 2$ to $240 \pm 30 \mathrm{ka} \mathrm{B.P.)}$ deposits (Tatumi et alli, 2006).

The colluvial deposits occur in patches on the Western Plateau of the State. They consist of structureless sands and rudites less than $10 \mathrm{~m}$ thick (Figure 2). When the contact with the underlying sandstones or basalts is exposed, it is unconformable. The presence of ferricretes and/or stonelines at the base of the colluvial deposits suggests the existence of a depositional hiatus. The basal ferricretes constitute locally interrupted, wavy beds, 2 to $40 \mathrm{~cm}$ thick, that contain fragmented ferricretes, rounded centimetric quartz or quartzite pebbles. These horizons always occur at the contacts between colluvial deposits and the Adamantina Formation, or as reworked and scattered fragments within colluvial deposits superimposed on the Serra Geral, Adamantina or Marília

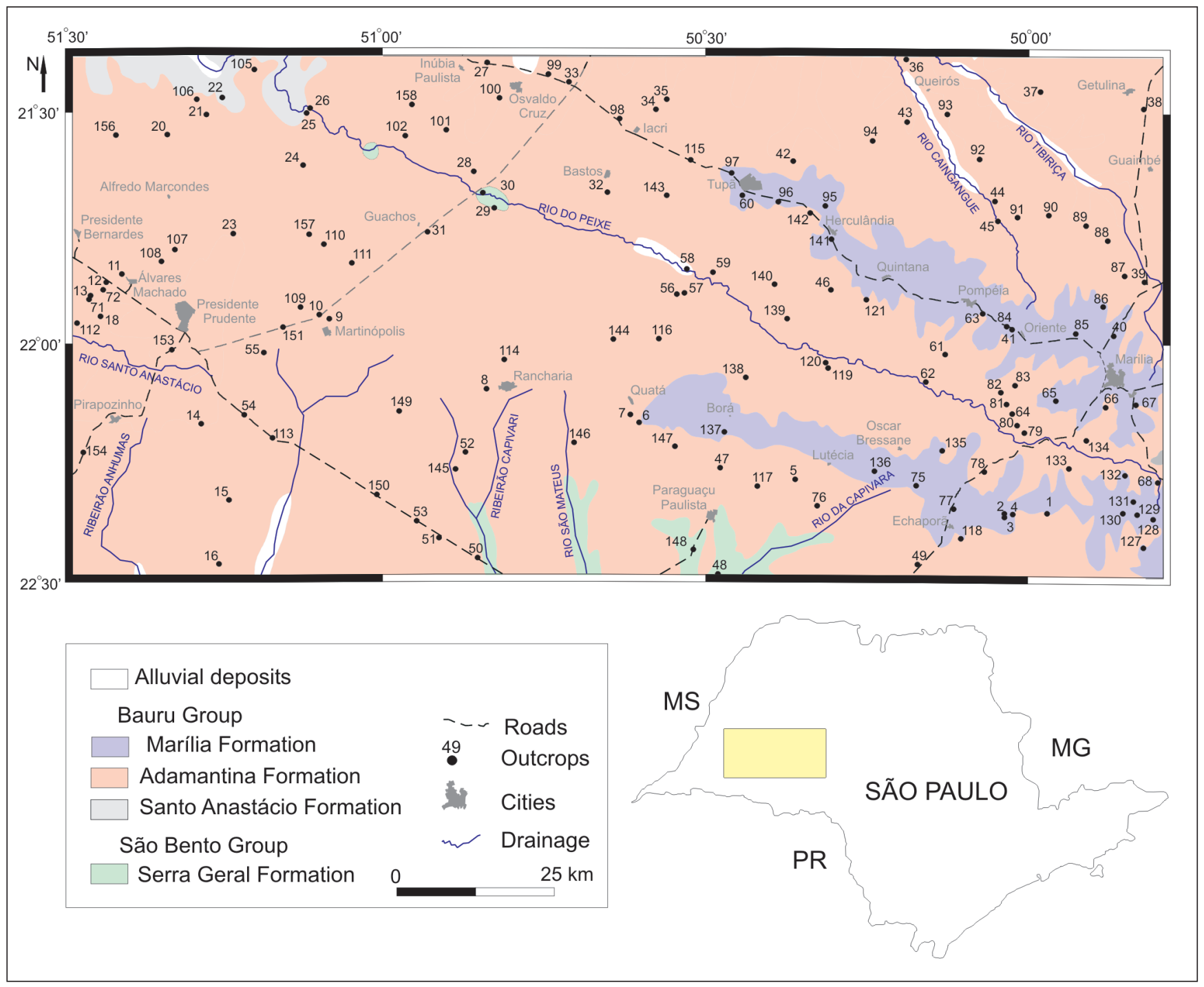

Figure 1 - Geographic and geologic location of the study area and sampling sites (geology according to Almeida et alli, 1981 and Milani and Ramos, 1998). 
Alethéa Ernandes Martins Sallun et al.

formations (Figure 3). The undulating beds or pseudofolding could represent a simple adaptation to a paleotopographic surface, but it is possible that the ferricrete bed faulting could be atectonic or even related to eventual neotectonic activities (Sallun, 2006).

The outcrop units are studied in detail from a sedimentologic viewpoint to determine their characteristics and provenance. The data obtained contributed to a better understanding of the region, the Quaternary geologic evolution of which remains largely unknown (Sallun, 2006).

\section{Materials and methods}

The field work consisted of sampling and visual description of geologic outcrops, distributed all over the studied area for sedimentologic analysis (Figure 1).

To determine the textural and mineralogical characteristics, 112 samples of colluvial deposits and 31 samples of sandstones of the Adamantina and Marília formations were collected. Where the colluvial deposits occurred above these sandstones, they were sampled for comparative textural and mineralogical studies. To characterize the textures, conventional grain-size analysis was performed. The fine $(0.250-0.125 \mathrm{~mm})$ and very fine $(0.125-0.062 \mathrm{~mm})$ sand fractions from 22 samples were separated into light and heavy minerals (Rittenhouse, 1943) according to differences in their density (Parfenoff, et alli 1970; Carver, 1971) using bromoform $\left(\mathrm{CHBr}_{3}\right)$. After separation, the light minerals were treated with $5 \%$ oxalic acid on hot aluminium plate for the lixiviation of ferruginous films found on the sand grains.

The light minerals were mounted on thin glass board. One hundred quartz grains were counted for morphologic and typological purposes. To determine quartz/feldspar ratios semiquantitatively, $\mathrm{X}$-ray diffraction analysis was performed after the rest of grains had been powdered in an agate mortar.

The heavy minerals were weighed to obtain the amount within the total sample. The heavy opaque minerals were separated using a hand magnet, according to Friedman (1958), 100 nonmicaceous transparent heavy minerals were identified and counted on the thin glass board. Remnant opaque minerals and clay-limonite nodules were excluded from counting on the thin glass boards.

To better interpret the meanings of non-micaceous transparent heavy minerals, the found frequencies of the assemblages were classified according to Coutinho and Coimbra's (1974) method, and ZTR index values were determined. These reflected the mineralogical maturity and corresponded to the content summation of the occurrences of zircon, tourmaline and rutile among these minerals.

In this study, similarities between the Quaternary and Cretaceous units were studied by comparing the grain-size data. Established statistical treatments for determinate types of environments were used, without any intention of defining or considering depositional environments for units, because the sediments can preserve the inherent characteristics of other depositional cycles.

For grain-size distribution data, the Folk and Ward (1957) graphic method was used to characterize the colluvial deposits and to enable comparison with the underlying Cretaceous sandstones of the Marilia and Adamantina formations that constitute the substrate. The statistical parameters were calculated for total and sandy distributions, because pelitic fractions can be subjected to illuviation during pedogenesis, which changes the original grain-size frequency.

After obtaining the Folk and Ward (1957) parameters, calculated for the sandy fractions of the samples, statistical analysis was used, as proposed by Friedman $(1961,1967)$ and Friedman and Johnson (1982).

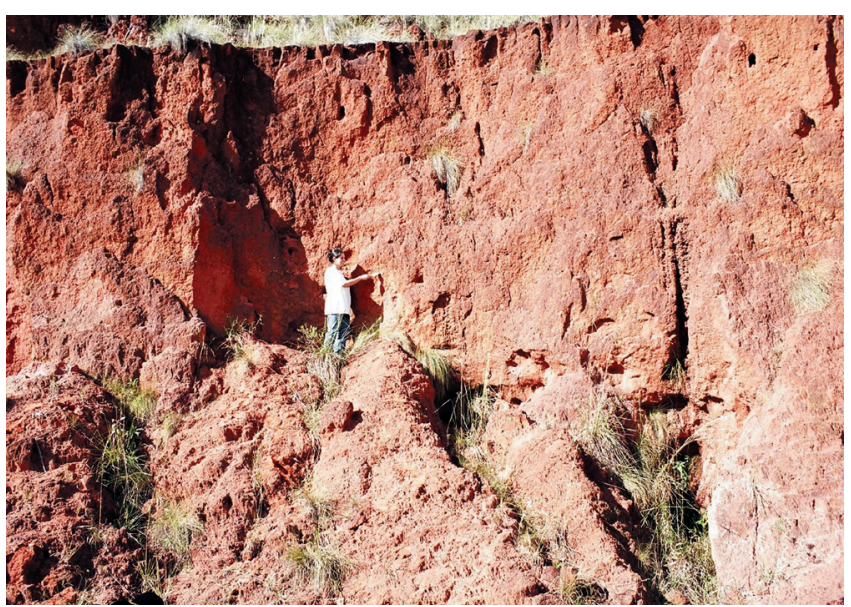

Figure 2 - Field appearance of the massive colluvial deposit (site 154).

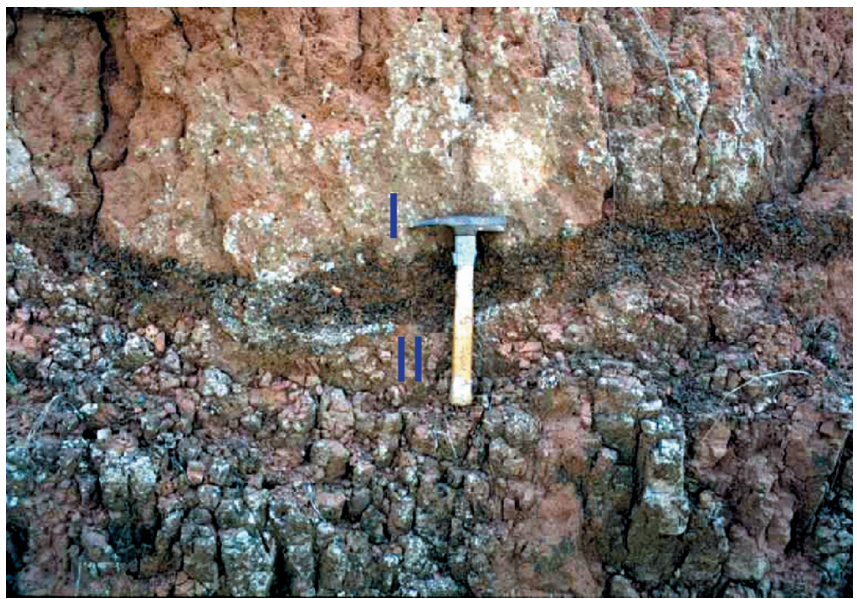

Figure 3 - Irregular ferricrete bed at the contact of Bauru Group sediments (II) and colluvial deposits (I), sampling site 102. 
For a more complete characterization of the ferruginous concretions, the following steps have been performed: chemical analysis (McFarlane, 1983) by X-ray fluorescence; petrographic study on a thin section; and surface textural analysis by scanning electron microscope (SEM). Chemical analyses of major, minor and trace elements have been performed on powdered representative samples.

\section{Results}

In order to compare the differences and similarities of the colluvial deposits and their underlying substrate, petrological and petrographic data were obtained from both colluvial cover and the Adamantina and Marília formations. Only a few outcrops of colluvial deposits superimposed on the Serra Geral Formation were studied so there is no statistical data; however, these deposits were subjected to mineralogical analysis and provenance studies.

\subsection{Grain size characteristics}

The analysis of the distribution of the grain-size fractions in the colluvial deposits shows: clays and silts are abundant in the NW and SE portions of the studied area, very fine-grained sand in the NW, fine sand in the centre and medium-grained sand in the SE. The thickest colluvial deposits are associated with sediments with abundant finegrained sand and scarce clays and silts. These differences can be observed also in the distribution of units in the Bauru Group, and might indicate transport of colluvial sediments from $\mathrm{E}$ to $\mathrm{W}$.

The studied units constitute 13 grain-size classes and the total cumulative curves for grain-size distribution demonstrate that, in general, these deposits are homogenous (Figure 4), consisting chiefly of sand, clayey sand and silty sand. Grain-size data for the majority of the samples are summarized in Table 1.

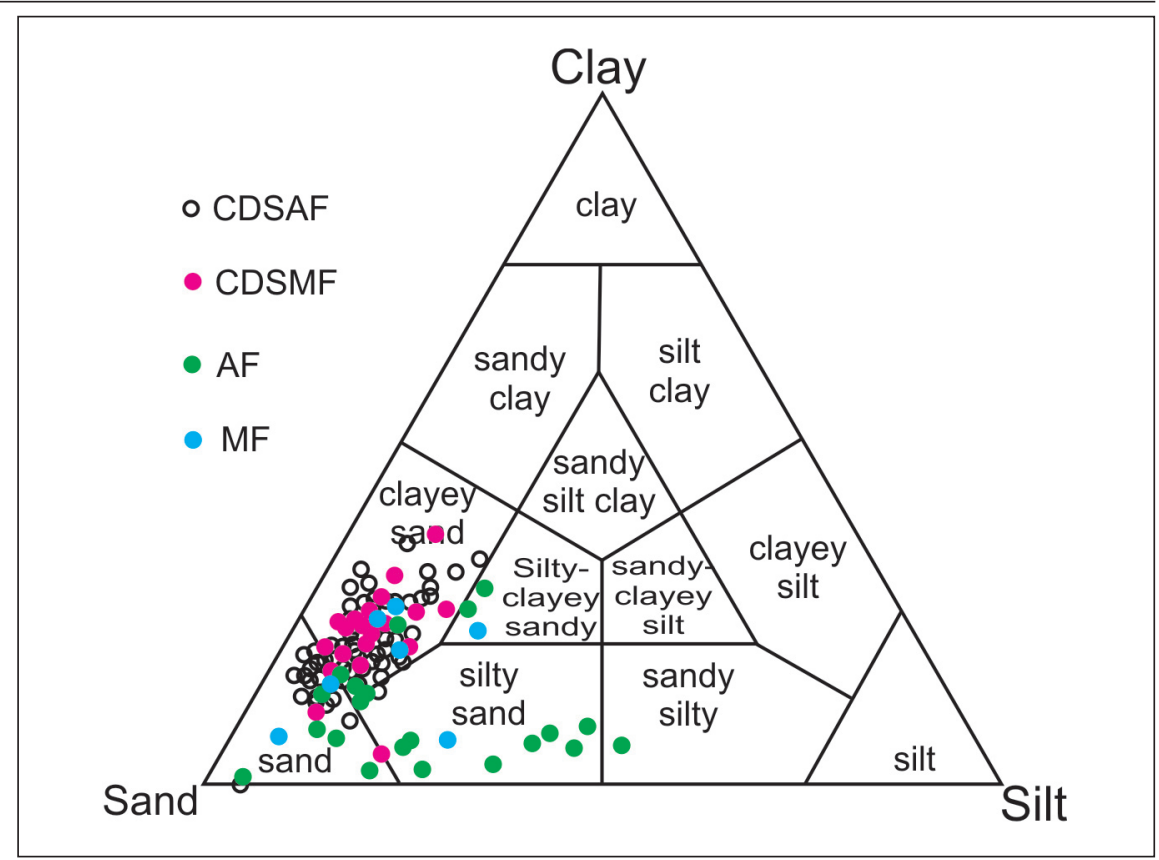

Figure 4 - The grain-size classification of the data obtained from colluvial deposits superimposed on the Marilia Formation (CDSMF), colluvial deposits superimposed on the Adamantina Formation (CDSAF), Marília Formation (MF) and Adamantina Formation $(A F)$, according to the triangular diagram proposed by Shepard (1954).

Table 1 - Summary of the data obtained for the majority of the studied units, colluvial deposits (CD), colluvial deposits superimposed to the Adamantina Formation (CDSAF), colluvial deposits superimposed to the Marília Formation (CDSMF), Adamantina Formation (AF) and Marília Formation (MF) (S-sand, CS-clayey sand, SS-silty sand, FS-fine sand, VFS-very fine sand, CS-coarse silt, VPS-very poorly sorted, PS-poorly sorted, MS-moderately sorted, WS-well sorted, VP-very positive, P-positive, ASi-approximately symmetrical, VL-very leptokurtic, VPL-very platikurtic, M-mesokurtic, L-leptokurtic).

\begin{tabular}{c|c|c|c|c|c}
\hline \multicolumn{7}{c}{ Total distribution } \\
\hline Units & CD & CDSAF & CDSMF & AF & MF \\
\hline Textural classes & 13 & 13 & 13 & 13 & 12 \\
\hline Major contribution & S and CS & S and CS & S and CS & S & S and SS \\
\hline Medium diameter & CS & CS & CS & CS and VFS & CS \\
\hline Sorting degree & VPS & VPS & VPS & PS & VPS \\
\hline Skewness & VP & P & VP & VP & VP \\
\hline Kurtosis & VL to VPL & VL to VPL & VL to VPL & VL to L & VL to VPL \\
\hline \multicolumn{7}{c|}{ Units } & CD & CDSAF & CDSMF & AF & MF \\
\hline Medium diameter & FS & FS & FS & FS and VFS & VFS \\
\hline Sorting degree & MS & MS & MS & WS & VPS \\
\hline Skewness & ASi & VP & ASi & ASi & VP \\
\hline Kurtosis & M & M & M & M & VL \\
\hline
\end{tabular}


Alethéa Ernandes Martins Sallun et al.

Most of the analyzed samples presented a fine grain size, from fine sand to coarse silt, with the finer portion being the worst sorted (Figure 5). The grainsize distributions were, in general, moderately sorted, which represents peculiarities inherited from most of the Bauru Group samples studied in the area.

Comparison of the units shows that the colluvial deposits present grain-size characteristics that are similar to their closely underlying rocks. The obtained values indicate fluvial and beach environments, but the Marília Formation samples and the colluvial deposits superimposed on the Marília Formation always indicate a fluvial environment (Figures 6A, B, E, F, G and J). The larger are the medium diameters, the smaller are the degrees of skewness and the standard deviations (Figures 6A, C, F and $\mathrm{H}$ ). The Adamantina Formation and the colluvial deposits superimposed on the Adamantina Formation exhibit higher sorting degrees than the Marília Formation and the colluvial deposits superimposed on the Marília Formation (Table 2).
Table 2 - Summary of the data obtained for total sand distribution of colluvial deposits (CD), colluvial deposits superimposed to the Adamantina Formation (CDSAF) and colluvial deposits superimposed to the Marília Formation (CDSMF). av= average, $\mathrm{Md}=$ medium diameter, $\sigma_{1}=$ standard deviation, $\mathrm{K}_{\mathrm{G}}=$ kurtosis and $\mathrm{SK}_{1}=$ skewness.

Total distribution

\begin{tabular}{c|c|c|c|c|c|c}
\hline Units & \multicolumn{2}{|c|}{ CD } & \multicolumn{2}{c|}{ CDSAF } & \multicolumn{2}{c}{ CDSMF } \\
\hline Values & max/min & av & max/min & av & max/min & av \\
\hline Md & $5.26 / 2.74$ & 4.43 & $5.26 / 3.23$ & 4.46 & $4.75 / 2.74$ & 4.28 \\
\hline$\sigma_{\mid}$ & $2.88 / 0.86$ & 2.53 & $2.88 / 1.74$ & 2.49 & $2.87 / 0.86$ & 2.56 \\
\hline $\mathrm{K}_{\mathrm{G}}$ & $2.63 / 0.52$ & 1.20 & $2.63 / 0.50$ & 1.28 & $2.83 / 0.52$ & 1.04 \\
\hline $\mathrm{SK}_{।}$ & $0.89 / 0.29$ & 0.63 & $0.89 / 0.29$ & 0.65 & $0.68 / 0.34$ & 0.56 \\
\hline
\end{tabular}

Sand distribution

\begin{tabular}{c|c|c|c|c|c|c}
\hline Units & \multicolumn{2}{|c|}{ CD } & \multicolumn{2}{c|}{ CDSAF } & \multicolumn{2}{c}{ CDSMF } \\
\hline Values & max/min & av & max/min & av & max/min & av \\
\hline $\mathrm{Md}$ & $3.49 / 1.90$ & 2.67 & $3.49 / 2.19$ & 2.73 & $2.63 / 1.90$ & 2.43 \\
\hline$\sigma_{\perp}$ & $1.03 / 0.37$ & 0.67 & $0.93 / 0.37$ & 0.64 & $1.03 / 0.63$ & 0.82 \\
\hline $\mathrm{K}_{\mathrm{G}}$ & $2.63 / 0.83$ & 1.00 & $2.63 / 0.85$ & 1.02 & $1.04 / 0.83$ & 0.92 \\
\hline $\mathrm{SK}_{\perp}$ & $0.35 /-0.30$ & -0.02 & $0.35 /-0.30$ & -0.03 & $0.15 /-0.13$ & -0.00 \\
\hline
\end{tabular}

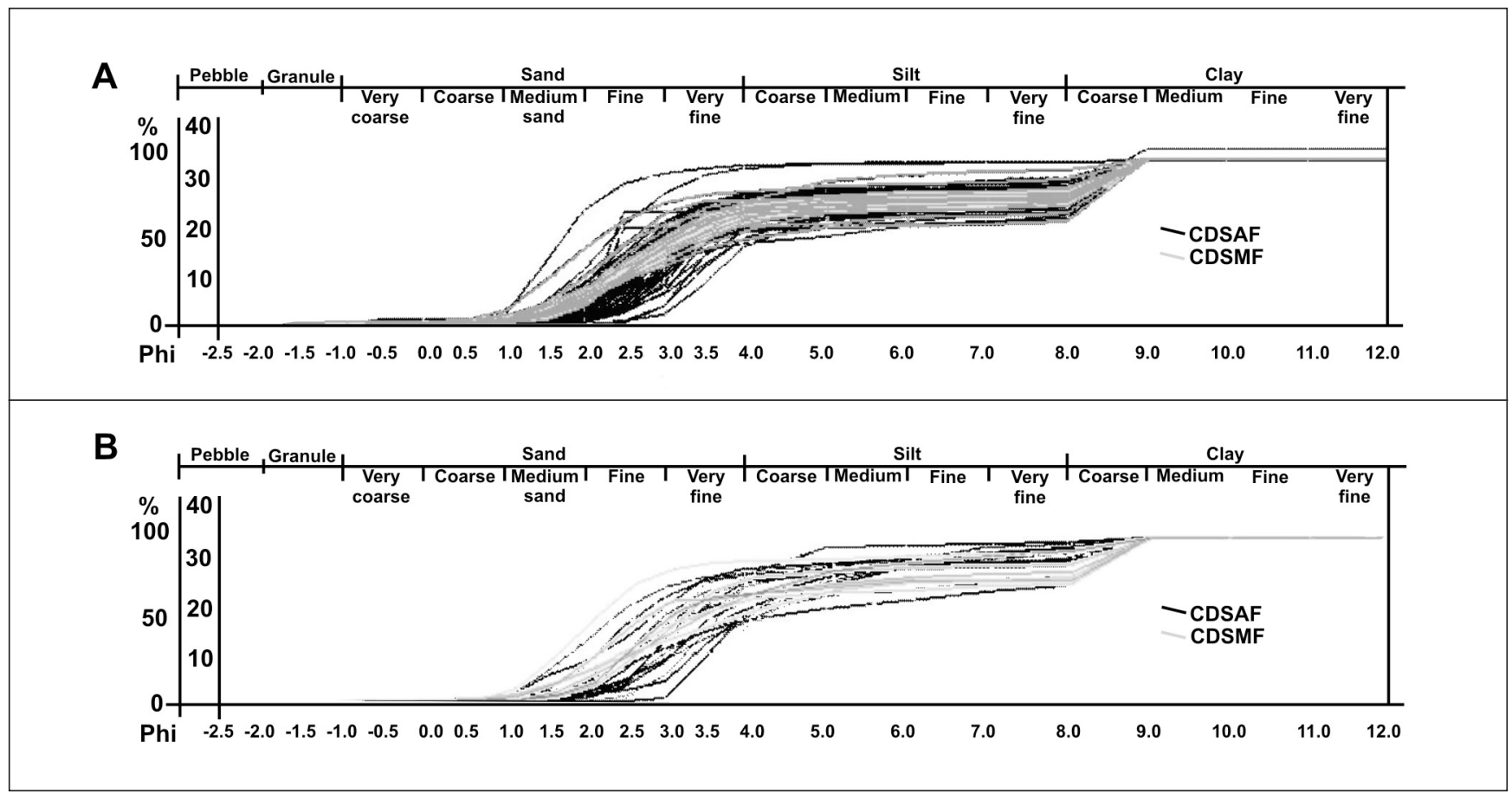

Figure 5 - Grain-size distribution cumulative curves of the data obtained from colluvial deposits superimposed on the Marilia Formation (CDSMF), colluvial deposits superimposed on the Adamantina Formation (CDSAF), Marília Formation (MF) and Adamantina Formation (AF). 
A

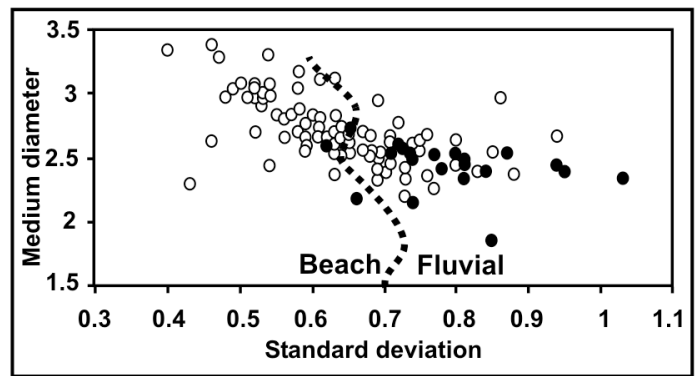

B

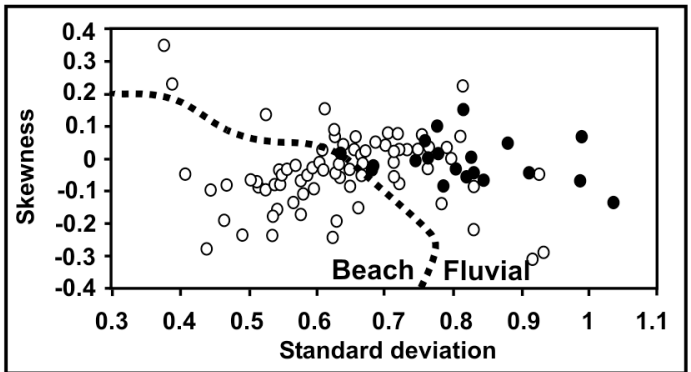

C

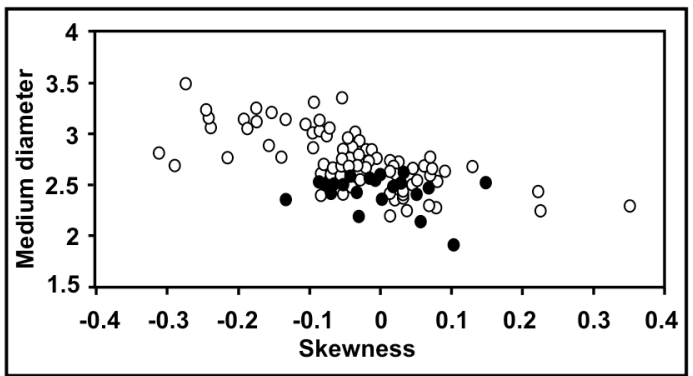

D

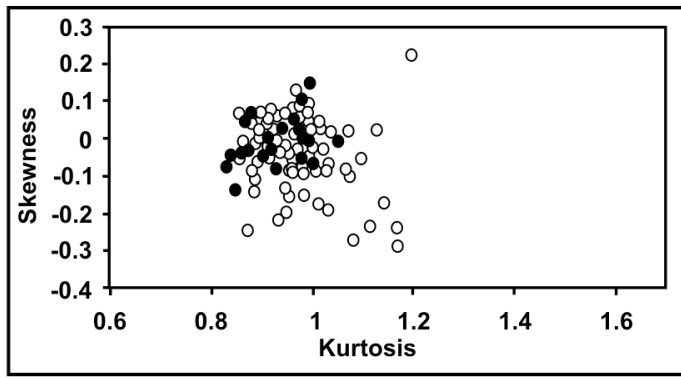

E

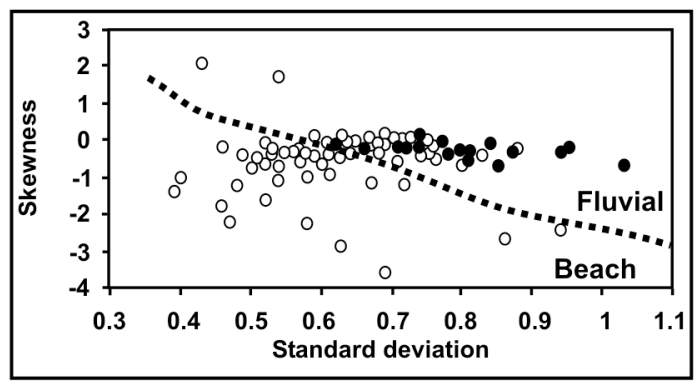

O CDSAF $\bullet$ CDSMF
$\mathbf{F}$

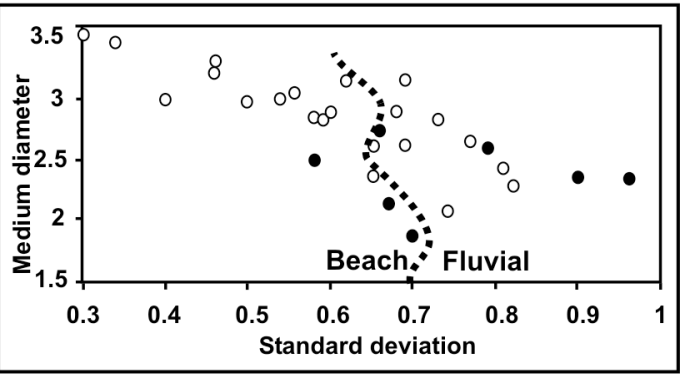

$\mathbf{G}$

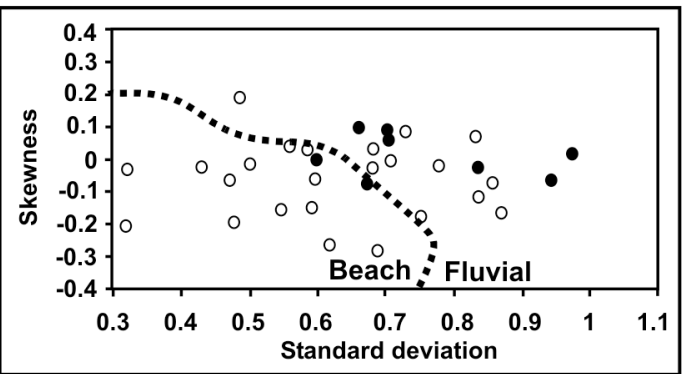

H

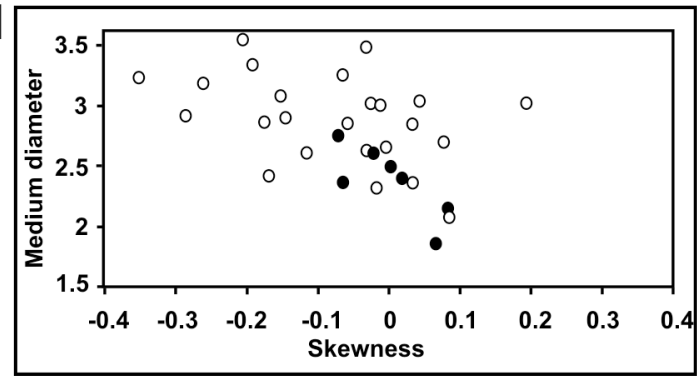

I

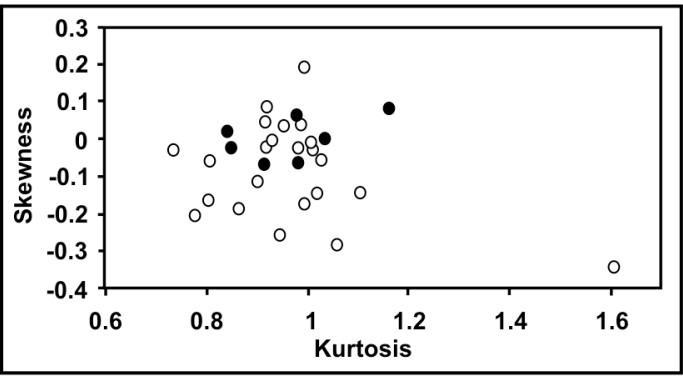

$\mathbf{J}$

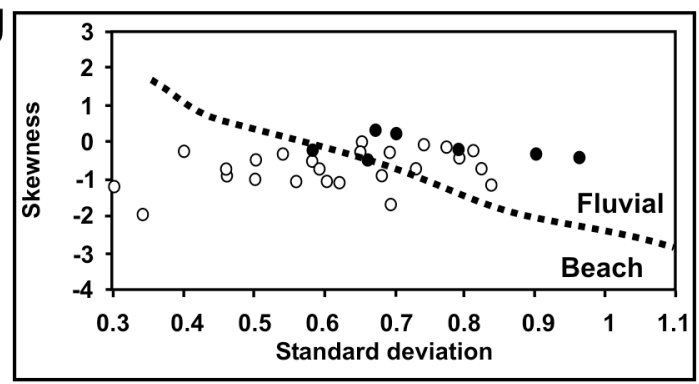

OAF

Figure 6 - Representations of the data obtained from colluvial deposits superimposed on the Marilia Formation (CDSMF), colluvial deposits superimposed on the Adamantina Formation (CDSAF), Marília Formation (MF) and Adamantina Formation (AF), according to the diagrams proposed by Friedman $(1961,1967)$. 
Alethéa Ernandes Martins Sallun et al.

For all units, the kurtosis values (Figures 6D and I) are concentrated around 0.8 to 1 (platikurtic to mesokurtic), while the medium diameters (Figures 6A, $\mathrm{C}, \mathrm{F}$ and $\mathrm{H}$ ) plotted between 3 and $2 \Phi$ (fine sand), and the degree of skewness (Figures 6B, C, D, G, H and I) lay between -0.1 and 0.1 (approximately symmetrical).

The comparison of results obtained for the total distribution showed that clay contents are higher in the colluvial deposits than in the Bauru Group. The sand distributions of the colluvial deposits and of Bauru Group rocks, when originated from the same outcrop, exhibited a generally good correlation between superimposed and underlying deposits.

\subsection{Mineralogical characteristics}

The heavy mineral contents of the colluvial deposits vary between $0.03 \%$ to $0.66 \%$ and $0.50 \%$ to $4.86 \%$ of the total weight in fine-grained and very finegrained sands, respectively (Table 3). Their frequencies are higher in very fine sands than in fine-grained sands. The magnetically heavy minerals represent $0 \%$ to $1 \%$ of the total heavy minerals within fine-grained and very fine-grained sands, except in sample 48-2, where magnetically heavy minerals represent $27.27 \%$ of the total heavy minerals. The colluvial deposits superimposed on the Serra Geral Formation exhibit a higher heavy mineral content than the other units studied.

\subsubsection{Light minerals}

In the analysis of light minerals present in the fine-grained sand fraction, only quartz grains are found in the colluvial deposits, while in the underlying Marília and Adamantina formations, feldspars ranging in content between $7 \%$ and $24 \%$ were found (Table 4 ).

As a sample, on site, 11 very finegrained sands of the colluvial deposits, quartz grains (up to $100 \%$ ), and feldspar (up to $4 \%$ ) were found, while in the underlying Marília and Adamantina formations quartz (up to $100 \%$ ), feldspars (up to 30\%) and calcite and dolomite (up to $4 \%$ ) were found.

\subsubsection{Heavy minerals}

During the petrographic study of non-micaceous transparent heavy minerals separated from fine and very fine-grained sands, the presence of zircon, tourmaline, staurolite and rutile was verified in all samples analyzed. Together with kyanite, they may be called superabundant (Tables 5, 6 and 7). The abundant minerals are sillimanita and garnet, and pyroxene is common.
In grain-size distributions of transparent heavy minerals in colluvial sediments, zircon and rutile are present in higher frequencies in very fine-grained sands, while tourmaline and staurolite $r$ are most abundant in fine-grained sands (Tables 5 and 6), due to differences in the specific gravities of these minerals (Tucker, 2001).

The distribution of heavy minerals in the study area show that in finegrained sand, tourmaline is the scarcest in the NW, while zircon and rutile are scarce in the E and S of the study area. In the very fine-grained sand, the amount of tourmaline is lower than in the finegrained sand. Zircon is more abundant

Table 3 - Maximum/minimum of total masses (\%) of heavy minerals for FS (fine-grained sands) and VFS (very fine-grained sands) of the studied units, colluvial deposits (CD), colluvial deposits superimposed to the Adamantina Formation (CDSAF), colluvial deposits superimposed to the Marília Formation (CDSMF), Adamantina Formation (AF) and Marília Formation (MF).

\begin{tabular}{c|c|c|c|c|c|c}
\hline Units & CD & CDSAF & CDSMF & CDSSGF & AF & MF \\
\hline FS & $0.66 / 0.03$ & $0.52 / 0.03$ & $0.66 / 0.32$ & $0.44 / 0.42$ & $0,28 / 0.04$ & $0.75 / 0.26$ \\
\hline VFS & $4.86 / 0.5$ & $1.81 / 0.5$ & $2.51 / 1.12$ & $4.86 / 4.32$ & $1.71 / 0.28$ & $2.65 / 1.57$ \\
\hline
\end{tabular}

Table 4 - Light mineral contents in fine- and very fine-grained sands of the colluvial deposits $(C D)$ and the Bauru Group (BG) sedimentary rocks, that occur at the same locality. $\mathrm{Qz}=$ quartz, $\mathrm{Fd}=$ feldspar and $\mathrm{CD}=$ calcite and dolomite

\begin{tabular}{c|c|c|c|c|c|c|c|c|c|c|c|c}
\hline \multirow{2}{*}{$\begin{array}{c}\text { Sampling } \\
\text { sites }\end{array}$} & \multicolumn{4}{|c|}{ Fine sand } & \multicolumn{5}{c|}{ Very fine sand } \\
\cline { 2 - 15 } & \multicolumn{2}{|c|}{ Qz } & \multicolumn{2}{|c|}{ Fd } & \multicolumn{2}{c|}{ CD } & \multicolumn{2}{|c|}{ Qz } & \multicolumn{2}{c}{ Fd } & \multicolumn{2}{c}{ CD } \\
\cline { 2 - 14 } & CD & BG & CD & BG & CD & BG & CD & BG & CD & BG & CD & BG \\
\hline 6 & 100 & 80 & 0 & 19 & 0 & 0 & 100 & 96 & 0 & 0 & 0 & 4 \\
\hline 10 & 100 & 100 & 0 & 0 & 0 & 0 & 100 & 70 & 0 & 30 & 0 & 0 \\
\hline 37 & 100 & 76 & 0 & 24 & 0 & 0 & 100 & 96 & 0 & 0 & 0 & 4 \\
\hline 45 & 100 & 100 & 0 & 0 & 0 & 0 & 100 & 100 & 0 & 0 & 0 & 0 \\
\hline 59 & 100 & 78 & 0 & 22 & 0 & 0 & 100 & 70 & 0 & 30 & 0 & 0 \\
\hline 63 & 100 & 100 & 0 & 0 & 0 & 0 & 97 & 100 & 0 & 0 & 3 & 0 \\
\hline 64 & 100 & 93 & 0 & 7 & 0 & 0 & 100 & 93 & 0 & 7 & 0 & 0 \\
\hline 77 & 100 & 100 & 0 & 0 & 0 & 0 & 100 & 100 & 0 & 0 & 0 & 0 \\
\hline 156 & 100 & 100 & 0 & 0 & 0 & 0 & 100 & 80 & 0 & 20 & 0 & 0 \\
\hline 157 & 10 & 91 & 0 & 9 & 0 & 0 & 10 & 100 & 0 & 0 & 0 & 0 \\
\hline
\end{tabular}


Sedimentological characterization of the quaternary deposits in the region between Marilia and ...

Table 5 - Contents of non-micaceous transparent heavy minerals in fine-grained sands of colluvial deposits (CD), and Bauru Group (BG) sedimentary rocks occurring in the same locality. Tour= tourmaline, Zir= zircon, Rut= rutile, Sta= staurolite, Gar= garnet, Kya = kyanite, Sil= sillimanite, $\mathrm{Py}=$ pyroxene and NO= Bauru Group, which does not occur in this locality.

\begin{tabular}{|c|c|c|c|c|c|c|c|c|c|c|c|c|c|c|c|c|}
\hline \multirow{2}{*}{$\begin{array}{l}\text { Sampling } \\
\text { sites }\end{array}$} & \multicolumn{2}{|c|}{ Tour } & \multicolumn{2}{|c|}{ Zir } & \multicolumn{2}{|c|}{ Rut } & \multicolumn{2}{|c|}{ Sta } & \multicolumn{2}{|c|}{ Gar } & \multicolumn{2}{|c|}{ Kya } & \multicolumn{2}{|c|}{ Sil } & \multicolumn{2}{|c|}{$\mathrm{Py}$} \\
\hline & CD & BG & CD & BG & $C D$ & BG & $C D$ & BG & $C D$ & BG & CD & BG & CD & BG & $C D$ & BG \\
\hline 6 & 58 & 56 & 15 & 17 & 0 & 0 & 0 & 0 & 0 & 0 & 0 & 0 & 2 & 0 & 0 & 0 \\
\hline 10 & 85 & 87 & 8 & 7 & 0 & 0 & 0 & 0 & 0 & 0 & 0 & 0 & 0 & 0 & 0 & 0 \\
\hline 11 & 89 & NO & 7 & NO & 0 & $\mathrm{NO}$ & 0 & $\mathrm{NO}$ & 0 & NO & 0 & NO & 0 & NO & 0 & $\mathrm{NO}$ \\
\hline 37 & 55 & 31 & 7 & 51 & 0 & 0 & 0 & 0 & 0 & 0 & 1 & 0 & 1 & 0 & 0 & 3 \\
\hline 45 & 67 & 67 & 13 & 23 & 0 & 0 & 0 & 0 & 0 & 0 & 0 & 0 & 0 & 1 & 0 & 1 \\
\hline 48 & 59 & NO & 11 & NO & 0 & $\mathrm{NO}$ & 0 & $\mathrm{NO}$ & 0 & NO & 0 & NO & 0 & NO & 0 & $\mathrm{NO}$ \\
\hline 50 & 47 & NO & 8 & NO & 0 & $\mathrm{NO}$ & 0 & $\mathrm{NO}$ & 0 & NO & 0 & NO & 0 & NO & 0 & $\mathrm{NO}$ \\
\hline 63 & 65 & 85 & 18 & 6 & 0 & 0 & 0 & 0 & 0 & 0 & 8 & 1 & 0 & 0 & 0 & 0 \\
\hline 64 & 8 & 43 & 15 & 7 & 0 & 28 & 0 & 28 & 0 & 28 & 1 & 0 & 0 & 0 & 0 & 5 \\
\hline 77 & 57 & 74 & 18 & 11 & 1 & 0 & 1 & 0 & 1 & 0 & 1 & 2 & 0 & 0 & 0 & 0 \\
\hline 115 & 78 & NO & 11 & $\mathrm{NO}$ & 0 & $\mathrm{NO}$ & 0 & $\mathrm{NO}$ & 0 & NO & 1 & NO & 0 & NO & 0 & $\mathrm{NO}$ \\
\hline 156 & 73 & 67 & 3 & 5 & 0 & 0 & 0 & 0 & 0 & 0 & 0 & 0 & 0 & 1 & 0 & 0 \\
\hline 157 & 74 & 71 & 12 & 17 & 0 & 0 & 0 & 0 & 0 & 0 & 0 & 0 & 0 & 1 & 0 & 1 \\
\hline
\end{tabular}

Table 6 - Contents of non-micaceous transparent heavy minerals in very fine-grained of colluvial deposits (CD), and Bauru Group (BG) sedimentary rocks occurring in the same locality. Tour= tourmaline, Zir= zircon, Rut= rutile, Sta= staurolite, Gar= garnet, Kya= kyanite, Sil= sillimanite, $\mathrm{Py}=$ pyroxene and $\mathrm{NO}=$ Bauru Group, which does not occur in this locality.

\begin{tabular}{c|c|c|c|c|c|c|c|c|c|c|c|c|c|c|c|c|c}
\hline \multirow{2}{*}{$\begin{array}{c}\text { Sampling } \\
\text { sites }\end{array}$} & \multicolumn{2}{|c|}{ Tour } & \multicolumn{2}{|c|}{ Zir } & \multicolumn{2}{|c|}{ Rut } & \multicolumn{2}{c|}{ Sta } & \multicolumn{2}{c|}{ Gar } & \multicolumn{2}{c|}{ Kya } & \multicolumn{3}{|c|}{ Sil } & \multicolumn{2}{c}{ Py } \\
\cline { 2 - 8 } & CD & BG & CD & BG & CD & BG & CD & BG & CD & BG & CD & BG & CD & BG & CD & BG \\
\hline 6 & 17 & 13 & 53 & 72 & 13 & 8 & 12 & 7 & 1 & 0 & 0 & 0 & 0 & 0 & 0 & 0 \\
\hline 10 & 12 & 65 & 71 & 11 & 13 & 9 & 4 & 3 & 0 & 0 & 0 & 4 & 0 & 8 & 0 & 0 \\
\hline 11 & 44 & NO & 26 & NO & 12 & NO & 8 & NO & 0 & NO & 9 & NO & 0 & NO & 1 & NO \\
\hline 37 & 21 & 14 & 60 & 75 & 9 & 7 & 6 & 2 & 0 & 0 & 0 & 0 & 4 & 0 & 0 & 2 \\
\hline 45 & 34 & 37 & 46 & 41 & 10 & 9 & 9 & 9 & 0 & 0 & 1 & 2 & 0 & 0 & 0 & 2 \\
\hline 48 & 30 & NO & 54 & NO & 7 & NO & 9 & NO & 0 & NO & 0 & NO & 0 & NO & 0 & NO \\
\hline 50 & 33 & NO & 47 & NO & 5 & NO & 15 & NO & 0 & NO & 0 & NO & 0 & NO & 0 & NO \\
\hline 63 & 33 & 31 & 38 & 52 & 8 & 2 & 4 & 6 & 0 & 0 & 16 & 0 & 0 & 0 & 1 & 9 \\
\hline 64 & 2 & 11 & 65 & 53 & 9 & 3 & 3 & 2 & 0 & 26 & 2 & 0 & 19 & 5 & 0 & 5 \\
\hline 77 & 19 & 33 & 62 & 49 & 10 & 3 & 5 & 8 & 0 & 0 & 4 & 2 & 0 & 0 & 0 & 0 \\
\hline 115 & 17 & NO & 60 & NO & 5 & NO & 9 & NO & 0 & NO & 1 & NO & 8 & NO & 0 & NO \\
\hline 156 & 40 & 45 & 44 & 49 & 2 & 3 & 14 & 2 & 0 & 0 & 0 & 2 & 0 & 5 & 0 & 0 \\
\hline 157 & 24 & 32 & 54 & 60 & 14 & 6 & 1 & 2 & 0 & 0 & 5 & 0 & 0 & 0 & 0 & 0 \\
\hline
\end{tabular}


Alethéa Ernandes Martins Sallun et al.

and is distributed more extensively. Rutile is the scarcest, but it is more abundant in the very fine-grained sand than in the fine-grained sand. Staurolite is the scarcerin the fine-grained sands.

Only six minerals appear in more than $25 \%$ of the studied samples of colluvial deposits: zircon, rutile and staurolite are more frequent in very finegrained sands, and tourmaline, kyanite and sillimanite are more frequent in finegrained sands. Seven minerals appear in more than $25 \%$ of the studied samples of Bauru Group sedimentary rocks: rutile, kyanite, sillimanite, zircon (more frequent in very fine-grained sands), and tourmaline, staurolite and pyroxene (more frequent in fine-grained sands).

The most peculiar characteristics of these heavy minerals are as follows (Figure 7):

a) Tourmaline: the shapes are spherical and well-rounded (Figures 7A and B), followed by rounded-edge prismatic forms (Figures 7C, D and F), while little-rounded prismatic forms with euhedral extremities are rarely found (Figures 7J, I and G). Some grains exhibit inclusions (Figures 7C, E and J), and brownish (ferromagnesian) and greenish (Figure 7G) colored grains are frequent but yellowish (magnesian Figures 7C, E, B, F and I), bluish (indicolite - Figures 7A and $\mathrm{H}$ ) and pinkish (Figures 7D and $\mathrm{J}$ ) colored grains are less common.

b) Zircon: the grains are colorless (Figure $7 \mathrm{~K}$ ) to slightly pinkish. Equidimensional and well-rounded shapes (Figure 7M) are most frequent, followed by rounded-edge prismatic (Figures 7L and $\mathrm{N}$ ), and bipyramidal prismatic forms. Zoning and inclusions are observed (Figures $7 \mathrm{~K}$ and L).

c) Rutile: the grains are reddish (Figure 7O), yellowish, yellowish red and almost opaque. They exhibit

Table 7 - ZTR index, contents of non-micaceous transparent heavy minerals zircon+ tourmaline+rutile, in fine- and very fine-grained sands of colluvial deposits (CD), and Bauru Group (BG) sedimentary rocks occurring in the same locality (NO= Bauru Group, which does not occur in this locality).

\begin{tabular}{c|c|c|c|c}
\hline \multirow{2}{*}{$\begin{array}{c}\text { Sampling } \\
\text { sites }\end{array}$} & \multicolumn{2}{|c|}{ Fine sand } & \multicolumn{2}{c}{ Very fine sand } \\
\cline { 2 - 5 } & CD & BG & CD & BG \\
\hline 6 & 81 & 78 & 87 & 93 \\
\hline 10 & 95 & 99 & 96 & 85 \\
\hline 11 & 97 & NO & NO & 82 \\
\hline 37 & 67 & 89 & 90 & 96 \\
\hline 45 & 91 & 90 & 90 & 87 \\
\hline 48 & 82 & NO & NO & 91 \\
\hline 50 & 58 & NO & NO & 85 \\
\hline 63 & 86 & 96 & 79 & 85 \\
\hline 64 & 30 & 53 & 76 & 67 \\
\hline 77 & 79 & 90 & 91 & 85 \\
\hline 115 & 91 & NO & NO & 82 \\
\hline 156 & 80 & 73 & 86 & 97 \\
\hline 157 & 92 & 88 & 92 & 98 \\
\hline
\end{tabular}

spherical and subrounded (Figure 70) forms, as well as prismatic forms suggestive of pyramidal terminations (Figure 7P). There are knees, heart or elbow-like twinnings with longitudinal and oblique striations (Figure 7O).

d) Garnet: the most common grains are colorless; few pinkish grains occur as well. Spherical and well-rounded shapes are dominant, but in Bauru Group sedimentary rocks there are elongated forms (Figure 7Q). Rectangular or losangular surface alteration (perforation) patterns are common.

e) Kyanite and sillimanite: the colorless grains (Figure 7R) exhibit elongated to spherical subrounded and euhedral shapes and display inclusions. Optical characteristics were used to distinguish between these polymorphs. f) Staurolite: there are irregular (Figures $7 \mathrm{~T}$ and $\mathrm{U}$ ) and rounded-edge prismatic (Figure 7S) grains with yellowish and yellow-reddish colors. They often exhibit zigzag saw-like edges (Figures 7T, U and V), providing the surface with a scalelike pattern (evidence of dissolution). They can present inclusions (Figure $7 \mathrm{~S})$.

g) Pyroxene: the grains exhibit elongated and rounded shapes with weathering features caused by indentations. Greenish (probably augite) or emerald-greenish (probably aegirine) colors are very common.

h) Epidote: the grains exhibit greenish color and are spherical.

i) Anatase: these grains occur only in the Bauru Group sedimentary rocks, displaying yellowish, light-bluish tones. They have a square and euhedral shape, which suggests that they are of authigenic origin. 


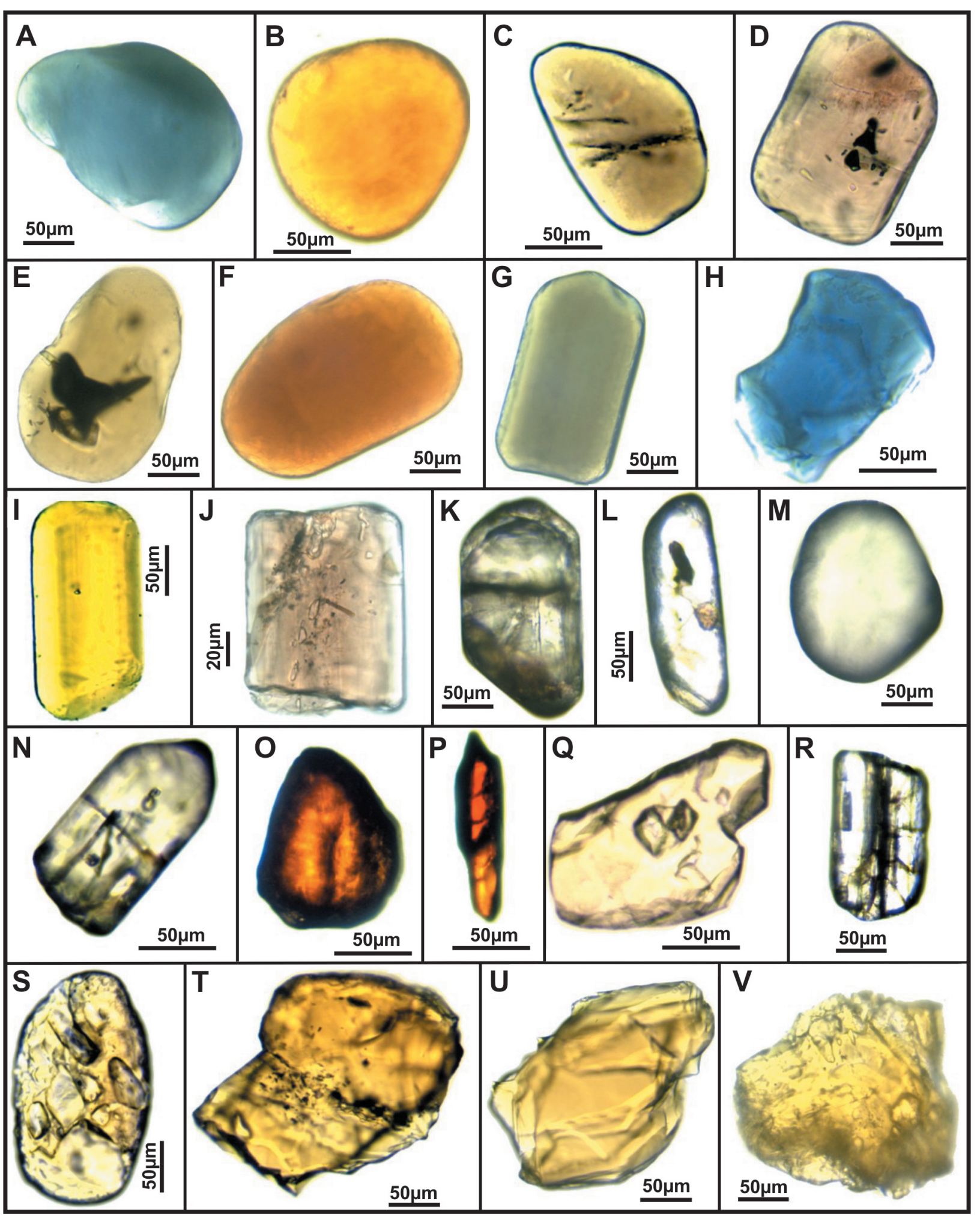

Figure 7 - Photomicrographs of non-micaceous transparent heavy minerals from fine- and very fine-grained sands of colluvial deposits (1) and from the Bauru Group (2). Tourmalines: well-rounded (1A and 1B), with prismatic inclusions (1C), rounded-edge $(1 \mathrm{D}, 2 \mathrm{E}, 2 \mathrm{~F}$ and $2 \mathrm{G})$, irregular blue $(2 \mathrm{H})$, with little rounded euhedral terminations (1I), prismatic pink with euhedral terminations and inclusions (2J); Zircon: prismatic colorless with zoning $(1 \mathrm{~K})$, with little rounded-edges $(1 \mathrm{~L})$ and spheric and well-rounded $1(\mathrm{M})$ and with inclusions $(2 \mathrm{~N})$; Rutile: prismatic red with subrounded edges (1O) and prismatic forms suggestive of pyramidal terminations with striations (2P); Garnet: pink to colorless with inclusions (2Q); Kyanite: prismatic colorless (1R); Staurolite: prismatic with rounded edges and inclusions (1S) and irregular yellow with zigzag saw-like edges (1T, $2 \mathrm{U}$ and $2 \mathrm{~V})$. 


\subsubsection{Ferricretes}

The ferricretes appear as aggregated blocks of concretions and nodules, concentric or nonconcentric, millimetric to centimetric, with irregular or spherical shapes and reddish colors (Figure 8). The aggregates contain fineto coarse-grained sands, essentially quartzose, with ferruginous (goethite) cementation. According to Bourman (1993), in similar deposits in Australia, this material could be interpreted as clastic deposits transformed into pisolitic and nodular ferricretes. They are found only overlying the colluvial deposits superimposed on the Adamantina Formation in 14 localities (Points 19, 21, 28, 43, 45, 48, 64, 71, 102, $108,134,156,157$ and 158) and as stoneline fragments at the base of colluvial deposits.

The ferricretes appear as aggregated blocks of concretions and nodules, concentric or nonconcentric, millimetric to centimetric, with irregular or spherical shapes and reddish colors (Figure 8). In thin sections, the aggregates contain fine- to coarsegrained sands, essentially quartzose, with ferruginous (goethite) cementation. According to Bourman (1993), in similar deposits in Australia, this material could be interpreted as clastic deposits transformed into pisolitic and nodular ferricretes. They are only found overlying the colluvial deposits superimposed on the Adamantina Formation in 14 localities (Points 19, 21, $28,43,45,48,64,71,102,108,134,156$, 157 and 158) and as stoneline fragments at the base of colluvial deposits.

In general the ferricretes show high $\mathrm{SiO}_{2}$ contents and lower $\mathrm{Fe}_{2} \mathrm{O}_{3}$ and $\mathrm{Al}_{2} \mathrm{O}_{3}$ contents (Table 8), or lower $\mathrm{SiO}_{2}$ contents and high $\mathrm{Fe}_{2} \mathrm{O}_{3}$. This suggests that they originated from sands or sandstones (Figure 9), and the high content of $\mathrm{SiO}_{2}$ is due to the presence of quartz.

The quartz grains of the ferricretes present corrosion features composed of superficial microfissures that suggest dissolution, which probably occurred due to strong weathering (Figure 10). The

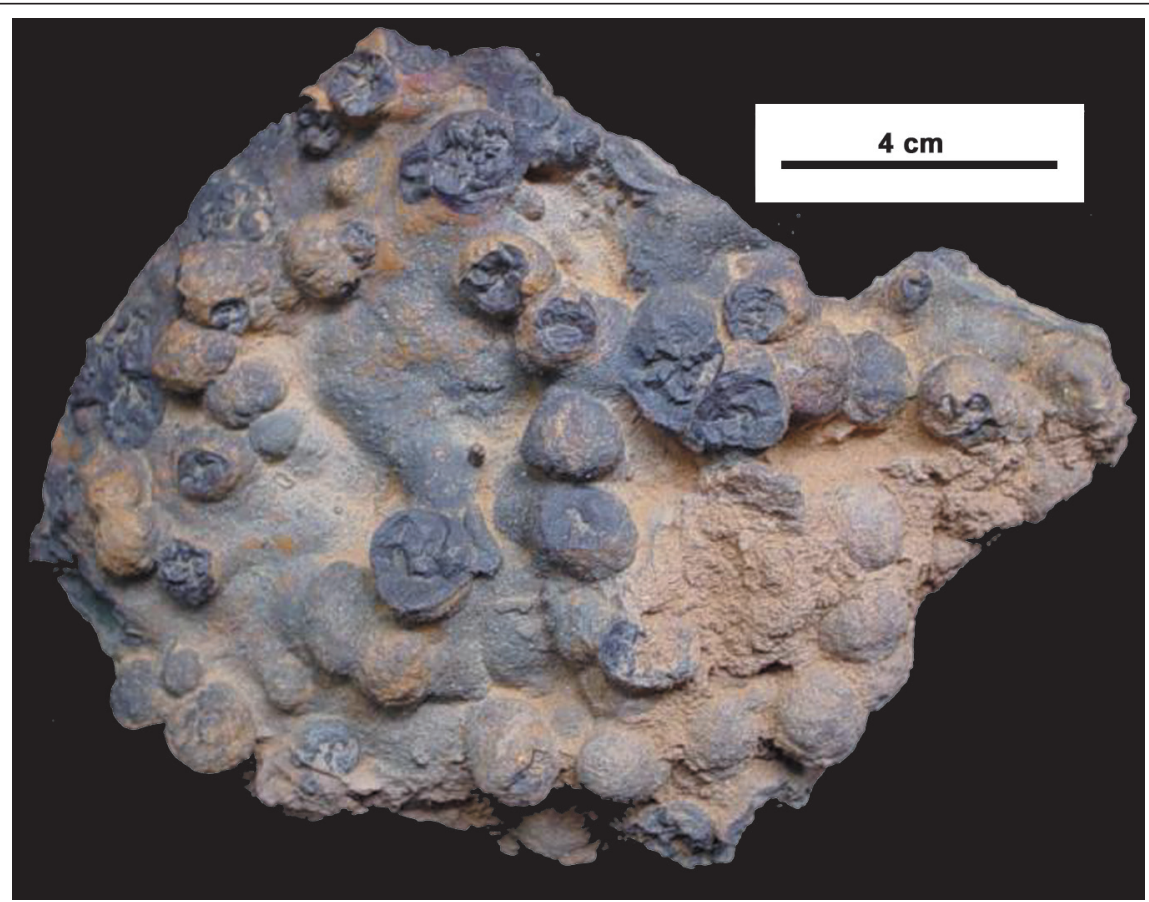

Figure 8 - Ferricrete fragment from site 45.

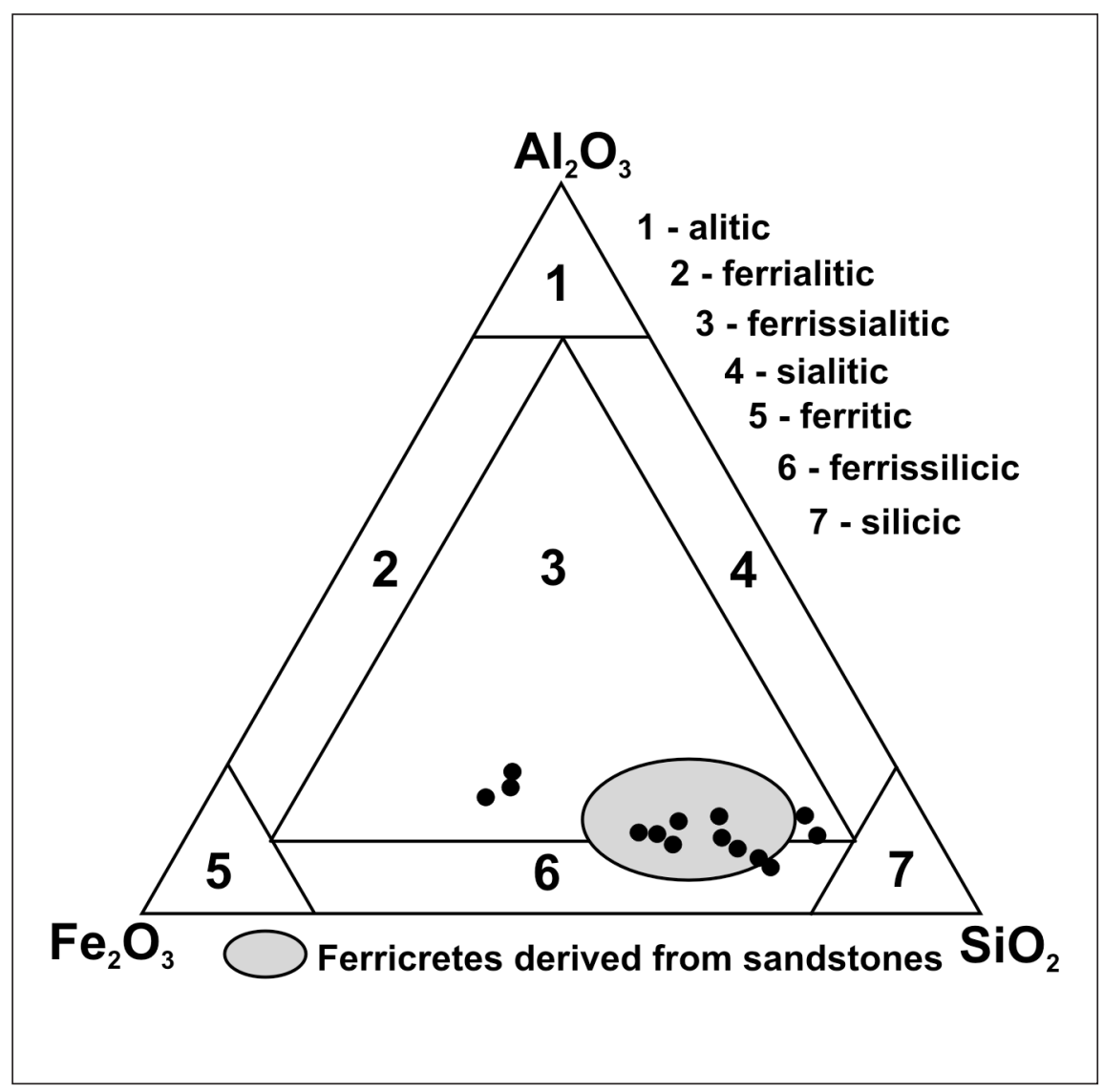

Figure 9 - Triangular diagram of ferricrete classification (modified from Dury 1969, MacFarlane 1983), with samples analyzed by the X-ray fluorescence method. 
Sedimentological characterization of the quaternary deposits in the region between Marilia and ...

Table 8 - Results of chemical analysis by X-ray fluorescence of selected elements, in percentages in weight of oxides. All Fe was calculated as $\mathrm{Fe}_{2} \mathrm{O}_{3}$, DL= detection limit and IL= ignition loss.

\begin{tabular}{c|c|c|c|c|c|c|c|c|c|c|c|c}
\hline Samples & $\mathrm{SiO}_{2}$ & $\mathrm{Al}_{2} \mathrm{O}_{3}$ & $\mathrm{MnO}$ & $\mathrm{MgO}$ & $\mathrm{CaO}$ & $\mathrm{Na}_{2} \mathrm{O}$ & $\mathrm{K}_{2} \mathrm{O}$ & $\mathrm{TiO}_{2}$ & $\mathrm{P}_{2} \mathrm{O}_{5}$ & $\mathrm{Fe}_{2} \mathrm{O}_{3}$ & $\mathrm{IL}$ & Total \\
\hline 19 & 65.03 & 7.55 & 0.024 & 0.26 & 0.02 & $<0.02$ & 0.38 & 0.781 & 0.040 & 21.25 & 4.50 & 99.84 \\
\hline 21 & 76.76 & 4.68 & 0.030 & 0.23 & 0.01 & $<0.02$ & 0.36 & 0.717 & 0.032 & 13.54 & 3.02 & 99.38 \\
\hline 28 & 52.36 & 6.87 & 0.020 & 0.06 & $<0.01$ & $<0.02$ & 0.07 & 0.668 & 0.046 & 34.48 & 5.86 & 100.43 \\
\hline 43 & 70.94 & 3.51 & 0.028 & 0.14 & 0.02 & $<0.02$ & 0.16 & 0.530 & 0.022 & 20.49 & 3.73 & 99.57 \\
\hline 45 & 12.08 & 5.72 & 0.206 & 0.10 & $<0.01$ & $<0.02$ & 0.10 & 0,228 & 0.255 & 69.11 & 12.26 & 100.06 \\
\hline 48 & 72.96 & 1.13 & 0.025 & 0.04 & 0.01 & $<0.02$ & 0.01 & 0.147 & 0.034 & 21.99 & 3.46 & 99.81 \\
\hline 58 & 66.60 & 4.07 & 0.109 & 0.42 & 0.03 & $<0.02$ & 1.10 & 0.567 & 1.077 & 21.14 & 4.95 & 100.06 \\
\hline 64 & 32.00 & 7.24 & 0.087 & 0.05 & $<0.01$ & $<0.02$ & 0.11 & 0.367 & 0.048 & 50.61 & 9.74 & 100.25 \\
\hline 71 & 62.39 & 7.83 & 1.290 & 0.24 & 0.04 & $<0.02$ & 0.37 & 1.190 & 0.568 & 19.47 & 6.34 & 99.73 \\
\hline 102 & 35.36 & 9.10 & 0.026 & 0.46 & 0.01 & $<0.02$ & 0.71 & 0.762 & 0.057 & 45.73 & 7.03 & 99.25 \\
\hline 108 & 37.87 & 9.27 & 0.053 & 0.44 & 0.02 & $<0.02$ & 0.64 & 1.783 & 0.139 & 43.36 & 6.74 & 100.32 \\
\hline 134 & 59.85 & 1.03 & 0.102 & 0.05 & $<0.01$ & $<0.02$ & 0.41 & 0.260 & 0.384 & 32.88 & 4.95 & 99.92 \\
\hline 156 & 73.44 & 4.85 & 0.020 & 0.21 & 0.04 & $<0.02$ & 0.28 & 0.600 & 0.052 & 16.59 & 3.74 & 99.82 \\
\hline 157 & 57.55 & 7.22 & 0.027 & 0.37 & $<0.01$ & $<0.02$ & 0.52 & 0.989 & 0.060 & 27.64 & 5.25 & 99.63 \\
\hline 158 & 57.55 & 7.84 & 0.032 & 0.44 & 0.06 & 0.17 & 0.70 & 0.909 & 0.071 & 27.66 & 3.59 & 99.02 \\
\hline $\mathrm{DL}$ & 0.01 & 0.01 & 0.002 & 0.01 & 0.01 & 0.02 & 0.01 & 0.007 & 0.003 & 0.01 & 0.01 & - \\
\hline & & & & & & & & &
\end{tabular}

dissolution is also responsible for the concentration of iron hydroxides (ferralitization). Goethite is currently present in the outer yellow or brown crust or within the nodules. The precipitation of iron hydroxides as concentric pore fillings suggests that there is iron remobilization through alternating dissolution and precipitation (Figure 11).

\section{Conclusions}

There are few differences in the grain-sizes between the Quaternary colluvial deposits and the Cretaceous sedimentary rocks of the Marília and Adamantina formations. Excluding the pelitic fraction (clay+silt) of the samples, the variability in grain-size distribution is diminished. The processes active in the formation of the colluvial deposits did not modify the grain-size distribution

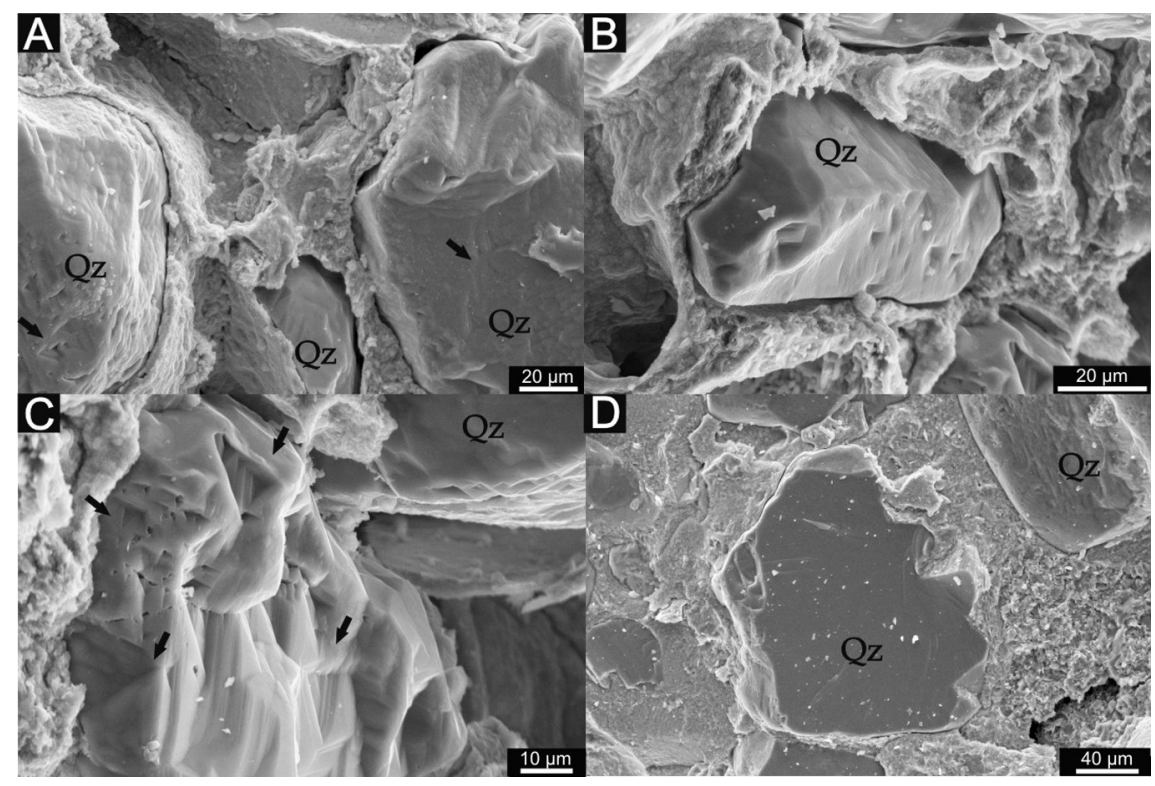

Figure 10 - Ferricrete photomicrographs obtained by SEM (scanning electron microscope), showing quartz grains with superficial corrosion features and surrounded by iron hydroxide cement; A, B and C - triangular geometric cavities "saw-teeth" type structure originated by chemical alteration. 
Alethéa Ernandes Martins Sallun et al.

of the sand fractions; changes occurred only in pelitic contents. The sorting degrees of the sand fractions were improved during pedogenetic processes and subsequent colluviation, which suggests that the pedogenetic processes attenuated the variability.

In general, the colluvial deposits are characterized by high mineralogical maturity expressed by higher values of the ZTR index ( $76 \%$ to $97 \%$ and $79 \%$ to $96 \%$ in fine-grained and very finegrained sands, respectively). These values change from $53 \%$ to $100 \%$ and $67 \%$ to $98 \%$ within the same fractions of the Bauru Group sedimentary rocks. In fine- and very fine-grained sand fractions, the mineralogical contents of colluvial deposits and of the Marília and Adamantina formations, when occurring at the same locality, show good correlation. However, there is a general enrichment of ultra stable minerals (zircon, turmaline and rutile), by elimination of less stable minerals (pyroxene and garnet), probably during eluviation and colluviation processes. There are small variations in the frequencies from the same outcrop, of tourmaline, staurolite, zircon and rutile in the fine-grained sand, and of tourmaline, staurolite, zircon, rutile and additionally kyanite and sillimanite in the very fine-grained sand fractions,

Moreover, when colluvial deposits and the sedimentary rocks of the Marília and Adamantina sandstones' heavy mineral assemblages from the same outcrop were compared, some minerals of metamorphic origin appeared only in colluvial deposits, including those superimposed on the Serra Geral Formation too. This fact could suggest an eventual contribution of eolian transportation processes or by creeping of the Bauru Group and Serra Geral weathered rocks, which contained heavy minerals (such as sillimanita, staurolite and pyroxene).

The ferricretes could have been formed through remobilization processes and the concentration of iron hydroxides by ancient groundwater level

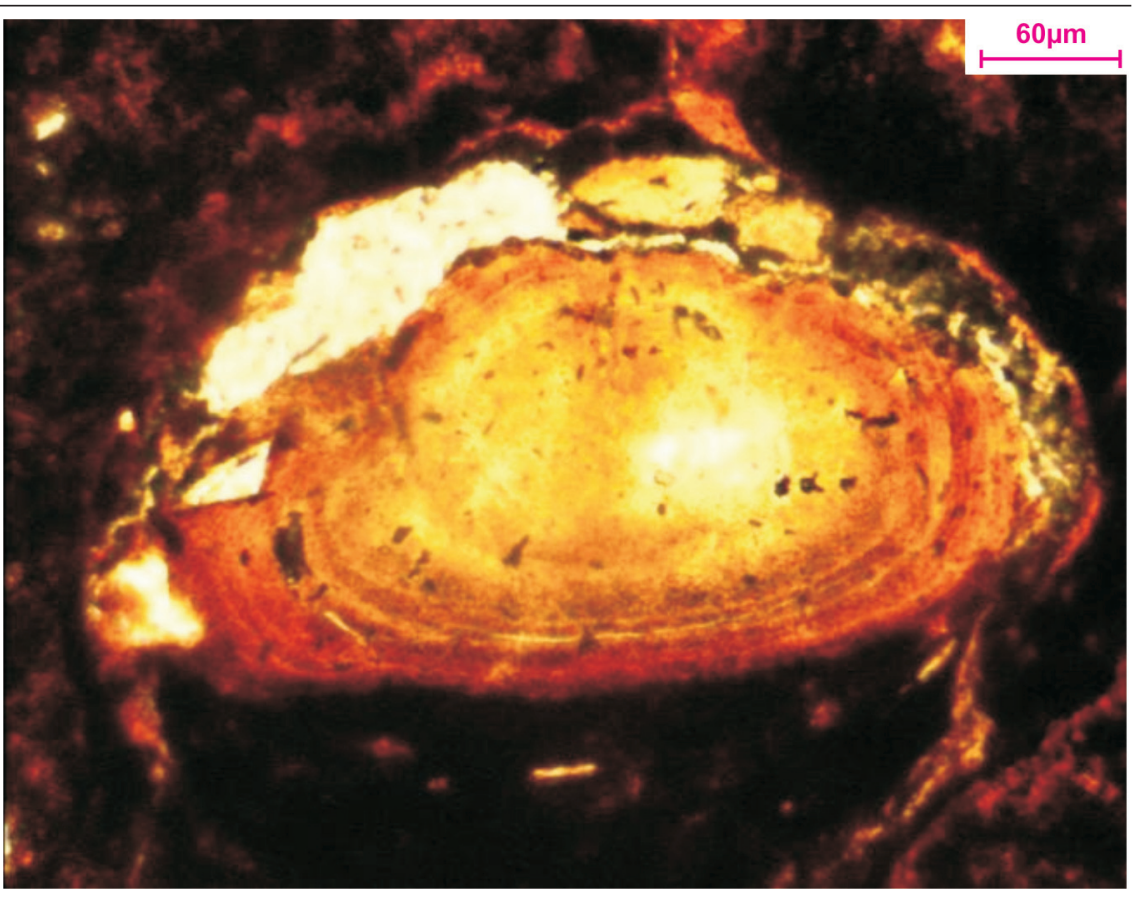

Figure 11 - Concentric structure within pore among quartz grains in ferricrete (thin section).

fluctuations induced by paleoclimatic changes and/or by relief uplift. The iron could have been leached from upstream and deposited in ancient vadose and phreatic zone interfaces, where wetter and drier conditions due to paleoclimate oscillations existed, which propitiated the precipitation of iron. Originally, these concretions might have exhibited considerable lateral extension. Later, the probable dismantling of the iron crusts promoted the transformation of hematite in goethite, which originated pisolitic horizons. The presence of quartz and the sandy composition of the ferricretes suggest a pedogenetic origin. The crust must have originated on the Bauru Group rock hills, which became resistant to erosion and, eventually, were molded to ancient surfaces probably of atectonic origin. The fragments could have been transported over short distances as the landscape evolved, and nowadays are mixed within the colluvial cover, as observed by Roquim (1990) in Mali.

The obtained data will subsidize future decisions on anthropogenic occupations, because this quaternary deposit exhibits high susceptibility for erosion and anthropogenic contaminations of soil and groundwater.

\section{Acknowledgements}

To FAPESP (Fundação de Amparo à Pesquisa do Estado de São Paulo) for Master and Doctoral scholarships (Processes 00/10672-6 and 03/01737-5) to the first author, and by a research grant to Kenitiro Suguio (Process 01/07469-7). To CNPq (Conselho Nacional de Desenvolvimento Científico e Tecnológico) by research Grant (Process 47404/2001-9 NV) and productivity scholarship to Kenitiro Suguio (Process 304718/2003-3).

\section{References}

ALMEIDA, F.F.M. de et alii. Mapa Geológico do Estado de São Paulo (escala 1:500.000). São Paulo: IPT, 1981. 126 p. (Publicação 1184, vol. I.).

BOURMAN, R.P. Modes of ferricrete genesis: evidence from southeastern Australia. Zeitschrift Für Geomorphologie, v. 37, p. 77-101, 1993.

CARVER, R.E. Procedures in Sedimentary Petrology. New York: J. Wiley, 1971. $653 \mathrm{p}$. 
COUTINHO, J.M.V., COIMBRA, A.M. Os pesados do Barreiras na Costa Oriental Brasileira: estudos de áreas-fonte. In: CONGR. BRAS. GEOL., 28, 1974. Porto Alegre. Anais... Porto Alegre: SBG, 1974. p. 27-41.

DIAS-BRITO, D. et alii. Grupo Bauru: uma unidade continental do Cretáceo no Brasil - concepções baseadas em dados micropaleontológicos, isotópicos e estratigráficos. Revue de Paléobiologie, v. 20, n.1, p. 245-304, 2001.

DURY, G.H. Perspectives on geomorphic processes. Washington: Association of American Geographers, 1969. 56p. (Resource Paper 3).

FOLK, R.L., WARD, W. Brazos River bar: a study in the significance of grain size parameters. Journal of Sedimentary Research, v. 27, p. 3-26, 1957.

FRIEDMAN, G.M. Determination of sievesize distribution from thin-section data for sedimentary petrological studies. Journal of Geology, v. 66, p. 394-416, 1958.

FRIEDMAN, G.M. Distinction between dune, beach and river sands from their textural characteristics. Journal of Sedimentary Petrology, v. 31, p. 514-524, 1961.
FRIEDMAN, G.M. Dynamic processes and statistical parameters compared for size frequency distribution of beach and river sands. Journal of Sedimentary Petrology, v. 37 , p. 327-353, 1967.

FRIEDMAN, G.M., JOHNSON, K.G. Exercises in Sedimentology. New York: Wiley, 1982. 208p.

McFARLANE, M.J. Laterites. In: GOUDIE, A.S., PYE, K. (eds.). Chemical Sediments and Geomorphology: precipitates and residua in the near-surface environment. London: Academic Press, 1983. p. 7-58.

MILANI, E.J., RAMOS V.A. Orogenias paleozóicas do domínio sul-oriental do Gondwana e os ciclos de subsidência da Bacia do Paraná. Revista Brasileira de Geociências, v. 28, n. 4, p. 473-484, 1998.

PARFENOFF, A. et alii. Le minéraux em grains. Paris: Masson et Cie, 1970. 580p.

RENNE, P. et alii. The age of Paraná Flood Volcanism, rifting of Gondwanaland, and the Jurassic-Cretaceous boundary. Science, v. 258, p. 975-979, 1992.

RITTENHOUSE, G. Transportation and deposition of heavy minerals. Geological Society of America Bulletin, v. 54, p. 1725-1780, 1943.

ROQUIM, C. Element distribution patterns in laterites of southern Mali: consequence for geochemical prospecting and mineral exploration. Applied Geochemistry, v. 5, p. 303315, 1990.

SALLUN, A.E.M., SUGUIO, K. Depósitos quaternários da região entre Marília e Presidente Prudente (SP). Revista Brasileira de Geociências, v. 36, n. 3, p.385-395, 2006.

SHEPARD, L.R. Nomenclature base don sand-silt-clay ratios. Journal of Sedimentary Petrology, v. 24, n. 3, p. 151-158, 1954.

TATUMI, S.H. et al. Luminescence dating of Quaternary deposits in geology in Brazil. Radiation Protection Dosimetry, v. 119, n. 1-4, p. 462-469, 2006.

TUCKER, M. E. Sedimentary petrology: an introduction to the origin of sedimentary rocks. Oxford: Blackwell, 2001.262 p.

Artigo recebido em 10/10/2007 e aprovado em 26/02/2008. 